\title{
$\$$ Research Square

\section{Cloning, expression, and functional characterization of an organophosphates insecticides degrading gene (opdC) from a potential probiotic Lactobacillus plantarum WCP931}

\section{Md. Azizul Haque}

Hajee Mohammad Danesh Science and Technology University

Hee Yul Lee

Gyeongnam National University of Science and Technology

Du Yong Cho

Gyeongnam National University of Science and Technology

Jin Hwan Lee

Dong-A University

\section{Chung Eun Hwang}

Gyeongnam National University of Science and Technology

Kye Man Cho ( $\sim$ kmcho@gntech.ac.kr)

Gyeongnam National University of Science and Technology https://orcid.org/0000-0002-5928-0532

\section{Original article}

Keywords: Organophosphorus insecticides, Kimchi, Lactobacillus plantarum WCP931, opdC gene, Biodegradation

Posted Date: April 21st, 2020

DOI: https://doi.org/10.21203/rs.3.rs-21471/v1

License: (c) (i) This work is licensed under a Creative Commons Attribution 4.0 International License. Read Full License 


\section{Abstract}

An organophosphorus (OP) insecticides degrading strain Lactobacillus plantarum WCP931, harboring OP hydrolase (OpdC) gene, was isolated during kimchi fermentation. The strain WCP931 appeared a significant survival rate of 51 to $96 \%$ under the artificial gastric acidic condition at pH 2 to 3 after $3 \mathrm{~h}$. The opdC gene consisting 831 bp encoding 276 amino acids was cloned from the strain WCP907. The recombinant Escherischia coli harboring opdC gene depleted 77\% chlorpyrifos (CP) in M9 medium after 6 days of incubation. The OpdC enzyme represents a novel member of GHSQG family of esterolytic enzymes or new Opd group. The OpdC molecular mass was estimated to be approximately $31 \mathrm{kDa}$ in SDS-PAGE and showed maximum activity at $40^{\circ} \mathrm{C}$ with $\mathrm{pH}$ 6. However, the mutated OpdC (Ser116 $\rightarrow$ Ala116) enzyme had no activity towards OP insecticides and $\rho$-nitrophenol- $\beta$-butyrate. Importantly, relative activity of OpdC against P-O bond insecticides was higher than P-S bond insecticide, which indicated its broad substrate specificity. It is suggested that opdC gene of strain WCP931 play role for the biodegradation of OP insecticides during kimchi fermentation.

\section{Introduction}

Chlorpyrifos (CP) is one of the most extensively applied organophosphorus (OP) insecticides worldwide (Ahmed et al. 2012). However, its residues persist in the environment for unpredictable period of time (Tariq et al. 2007) and may enter vegetables cultivated on the polluted sites and pose a great threat to the human health (Huete-Soto et al. 2017). The environmental fate of CP has been extensively studied, and its half-life in soil varies from 10 to 120 days (Haque et al. 2018; Getzin 1981) resulting in 3,5,6-trichloro2-pyridinol (TCP) as the major degradation product. Hwang and Moon (2018) reported that the levels of $\mathrm{CP}$ residue in Korean Cabbages were ranged between $0.12 \sim 0.75 \mathrm{mg} / \mathrm{kg}$ after $32-35$ days of CP $\left(0.24 \sim 0.72 \mathrm{~g}\right.$ a.i. $\left./ \mathrm{m}^{2}\right)$ treatment in different cabbage fields. Yu et al. (2006) reported that the CPdegrading fungal strain Vertcillium sp. being used in detoxification of the insecticide on vegetables. In previously, Cho et al. (2009a) investigated that lactic acid bacteria (LAB), including Leuconostoc genus (L. mesenteroides WCP907) and Lactobacillus genus (Lactobacillus brevis WCP902, Lactobacillus plantarum WCP931, and Lactobacillus sakei WCP904), could utilize OP insecticides as a source of carbon and phosphorus in a defined medium and decontaminated the insecticides in kimchi vegetables during fermentation.

L. plantarum, like all probiotics, is a beneficial bacterium that can be used for improved health. It has been shown to be an effective treatment for promoting normal digestive health, irritable bowel syndrome (Ducrotte et al. 2012), Crohn's disease, and colitis. This bacterium is acid and bile salt tolerant, which allows it to survive the passage through the gastrointestinal tract of humans (Cebeci and Gurakan, 2003). It can destroy potential pathogens such as Listeria monocytogenes, Escherischia coli, Yersinia enterolytica, Enterobacter cloacae and Enterococcus faecalis and preserve critical nutrients, vitamins, and antioxidants (Johansson 1998; Siroli et al. 2015). L. plantarum also has beneficial immuno-modulatory activity via an increased interleukin-10 synthesis and secretion in macrophages and T-cells derived from the inflamed colon. (Mark 2003). 
Characters of fermented kimchi are originated by the action of LAB during fermentation. On the basis of acidity, kimchi fermentation was divided into five stages: initial stage, immature stage, optimum-ripening stage, over-ripening stage, and rancid stage (Cho et al. 2009b). In previous reports, kimchi fermentation is dominated by Lactobacillus sp. and Leuconostoc sp. (Cho et al. 2009b; Kim et al. 2012; Park et al. 2006). In fact, the population density of $L$. mesenteroides reached to its maximum during the main ripening period of kimchi and then declined as the $\mathrm{pH}$ of kimchi decreased, whereas that of acid tolerant lactobacilli such as L. plantarum continued to increase until the last stage of fermentation (Cho et al. 2009 b). Although L. plantarum probiotic has involved in multiple health benefits, but its biodegradation ability to OP insecticides was unknown. We first report the role of $L$. plantarum in biodegradation of OP insecticides (Cho et al. 2009a). Zhang et al. (2014) reported relationship of phosphatase from LAB including L. plantarum and OP insecticides degradation in skimmed milk and Harishankar et al. (2013) reported the in vitro degradation of chlorpyrifos using intenstinal bacterium L. plantarum.

However, the gene of $L$. plantarum responsible for the degradation of OP insecticides is not revealed yet. In this study, an OP insecticides hydrolase gene (named $o p d C$ ) is cloned from potential probiotic strain $L$. plantarum WCP931 and its purified recombinant OpdC enzyme is characterized. The site directed mutagenesis and bioinformatics tools analysis predicted the potential active site of OpdC enzyme that played vital role for the degradation of nerve poisoning organophate insecticides. This study first time reveals the cloning and functional characterization of an opd gene from the potential probiotic $L$. plantarum WCP931 which augmented the diversity of opd gene in nature.

\section{Method And Materials}

\section{Strains, plasmids, media and chemicals}

The strains E. coli DH5a, BL21 (DE3), and recombinant E. coli cells (expressing opdC gene) were cultured at $37^{\circ} \mathrm{C}$ in a Luria-Bertani (LB) medium and $\mathrm{M} 9$ medium supplemented with the appropriate antibiotics. The Luria Beratani (LB), lactobacilli MRS (MRS), and minimal nutrient (M9) medium were purchased from Difco Co. (MD, USA). The pGEM-T easy vector (Promega Co., Madison, WI, USA) was used for cloning and sequencing of the interest genes. The vector pBluescript II SK(+) and pET32a ${ }^{(+)}$(Stratagene, CA, USA) was used for subcloning and over-expression as well as purification of the gene product. The OP insecticides such as chlorpyrifos (CP), cadusafos (CS), coumaphos (CM), diazinon (DZ), dyfonate (DF), ethoprophos (EP), fenamiphos (FA), methylparathion (MPT), and parathion (PT) and the two chemicals including 3,5,6trichloro-2-pyridinol (TCP) and diethylthiphosphoric acid (DETP) were obtained from the Sigma-Aldrich, Inc. (Germany). To determine esterase activity, the tributyrin, $\rho$-nitrophenol- $\beta$-butyrate $(\rho-\mathrm{NPB})$, and $\rho$ nitrophenol ( $\rho$-NP) were also purchased from Sigma-Aldrich, Inc. (Germany). The genomic and plasmid DNAs were isolated using the G-spin genomic DNA extraction and Plasmid DNA Purification Kits (iNtRON Biotechnology, South Korea). The restriction enzymes were purchased from Gibco-BRL (Thermo Fisher Scientific Co., USA) and Promega Co. (USA). The HPLC-grade water, all the other reagents were of analytical grade. 


\section{Identification of strain WCP931 and determination of acid and artificial gastric acid tolerances}

The OP insecticides degrading strain WCP931 was isolated from mulkimchi sample and identified as previously described by Haque et al. (2018). The acid and gastric acid tolerance activity of the strain $L$. plantarum WCP931 was further confirmed previously by Cho et al. (2008).

\section{Degradation of CP and substrate range test in liquid medium}

The bacterial strain L. plantarum WCP931 grown in MRS broth was used as inoculum for the degradation of $\mathrm{CP}$ in liquid medium. A total of $500 \mu \mathrm{L}$ of bacterial culture suspension $\left(10^{8} \mathrm{cfu} / \mathrm{mL}\right)$ was inoculated into $50 \mathrm{~mL}$ of $1 / 25 \mathrm{MRS}$ medium with CP $(100 \mathrm{mg} / \mathrm{L})$. The $E$. coli DH5a was cultured as the control in the similar conditions. The recombinant E. coli DH5a (pGCY300) growth was also confirmed in the M9 medium with CP (100 mg/L). Moreover, CS, CM, DZ, DF, EP, FA, MPT, and PT cross feeding were also performed using the identical condition. At periodic intervals, an individual flask was sacrificed and its contents were used to determine the growth and degradation of OP insecticides. The cultures were run in triplicate to ensure the accuracy.

\section{OP insecticides degradation and esterase activity assay}

The OP insecticides and its residue concentrations, after degrading by the strain WCP931, recombinant $E$. coli, and OpdC protein were determined using TLC and HPLC methods according to previously described Cho et al. (2009a). A $5 \mathrm{~mL}$ of supernatant was collected from the culture and $4 \mathrm{~mL}$ of the culture filtrate was extracted with ethyl acetate $(8 \mathrm{~mL} \times 3)$. The TLC plate was developed for the analysis of degradation of CP and TCP as described by Islam et al. (2010). However, the degradation of CP, CM, CS, DZ, DY, EP, FA, MPT, and PT was determined according to the changes of absorbance at $214 \mathrm{~nm}$ measured by a High press liquid chromatography (HPLC) (Perkin-Elmer 200 series, CT, USA). The $50 \mu \mathrm{L}$ enzyme sample was added to an assay mixture containing $700 \mu \mathrm{L}$ phosphate-buffer saline $(200 \mathrm{mM}, \mathrm{pH} 6.5)$ and $250 \mu \mathrm{L} \mathrm{CP}$, $\mathrm{CM}, \mathrm{CS}, \mathrm{DZ}, \mathrm{DY}, \mathrm{EP}, \mathrm{FA}, \mathrm{MPT}, \mathrm{PT}(200 \mathrm{mg} / \mathrm{L})$, and was incubated at $30^{\circ} \mathrm{C}$ for $12 \mathrm{~h}$, respectively. After that $10 \mu \mathrm{L}$ of the filtrate that was mixed with methanol and passed through a $0.45-\mu \mathrm{m}$ PVDF filter $(\mathrm{GmbH}$, Dassel, Germany) and was injected into a C18 column ( $250 \times 4.6 \mathrm{~mm}, 5 \mu \mathrm{m}$, Phenomenex, CA, USA) of HPLC. The concentration of the degraded insecticides residues were determined according to the peak areas in the chromatograms against standard pesticides as described Cho et al. (2009a), Islam et al. (2010), and Haque et al (2018). The OP insecticides degradation and its estimation were repeated in three times to obtain the standard error of the experiments.

The esterase activity of OpdC and mutant OpdC enzyme was determined by a spectrophotometric method. The rate of hydrolysis of $\rho$ NPB $(100 \mathrm{mg} / \mathrm{L})$ at $30^{\circ} \mathrm{C}$ was measured in $50 \mathrm{mM}$ sodium phosphate buffer ( $\mathrm{pH} \mathrm{7.0)}$ by a spectrophotometer at $420 \mathrm{~nm}$. One unit of esterase was defined as the amount of enzyme required to release $1 \mu \mathrm{mol}$ of $\rho \mathrm{NP}$ per minute under the assay conditions. All the experiments were conducted in triplicate to reveal the error. 
The complete open reading frame of opdC from L. plantarum WCP931 genomic DNA was amplified using 5'-AAA GGA TCC TGA TTG ATC TGA CAA TGG G-3' (sense, BamHI sites are indicated by underline), 5'-AAA GAA TTC CTT GCT ATA CTG ATT CGC TAG CC-3' (antisense, Hindlll sites are indicated by underline) primers sequence based on the carboxylesterase available in the database, and cloned into PGEM-T easy vector (Promega, Madison, WI, USA). The recombinant plasmid was digested with BamHI and Hindll and cloned into pBluscript II SK+ digested with the same restriction enzyme. The nucleotide and amino acid sequences were determined and analyzed as described by Islam et al. (2010) and Haque et al. (2018). The phylogenetic tree and alignment of conserved regions of the OpdC protein with other Opd enzymes and esterolytic enzymes amino acid sequences was analyzed using DNAMAN10.0 software package (Haque et al. 2018).

\section{Expression and purification of the OpdC enzyme}

To facilate high expression levels of OpdC, the PCR product generated with primers 5'-AAA GGA TCC TGA TTG ATC TGA CAA TGG G-3' (sense, BamHI sites are indicated by underline), 5'-AAAA GA ATT CCT TGC TAT ACT GAT TCG CTA GCC-3' (antisense, Hindll sites are indicated by underline) was cloned into expression vector pET-32a(+) (Novagen), resulting in the addition of a C-terminal ( $\mathrm{His})_{6}$ tag. The E. coli strain BL21 (DE3) carrying pET-32a(+)/OpdC was grown at $37^{\circ} \mathrm{C}$ to mid-log phase in LB medium containing $50 \mu \mathrm{g} / \mathrm{mL}$ ampicillin, respectively. The pellet of recombinant $E$. coli cells was made and washed with $10 \mathrm{mM}$ Tris- $\mathrm{HCl}$ buffer ( $\mathrm{pH}$ 7.0). Thereafter the pellet was resuspended in the same buffer and kept at $-20^{\circ} \mathrm{C}$ for $30 \mathrm{~min}$. Next, it was mixed with $1 \mathrm{mg}$ of bovine DNase I and incubated at $37^{\circ} \mathrm{C}$ for $30 \mathrm{~min}$. Triton X-100 was added to the suspension to set a final concentration of $2.5 \%$. The supernatant was collected and stored at $4{ }^{\circ} \mathrm{C}$. The solubilized recombinant OpdC with His-tag was applied on a HisTrap kit (Amershan Pharmacia Biotech). The purification of expressed His ${ }_{6}$-tagged OpdC protein was conducted and eluted with $100 \mathrm{mM}$ imidazole with $0.1 \%$ Triton X-100 as described Islam et al. (2010). The molecular weight of purified OpdC was determined by sodium dodecyl sulfate-polyacrylamide gel electrophoresis analysis. The amount of OpdC in the solution was adjusted at $50 \mu \mathrm{g} / \mathrm{mL}$ and was used for activity assay towards organophosphate insecticides.

\section{pH and temperature stability of OpdC enzyme}

The effect of $\mathrm{pH}$ and temperature on esterase activity was investigated using purified OpdC protein. The effects of $\mathrm{pH}$ and temperature on the esterase activity were examined with the purified recombinant enzyme. The effect of $\mathrm{pH}$ on the esterolytic activity was determined by using above mentioned protocol, to obtain values from $\mathrm{pH} 3.0$ to 11.0 ; all of the assays were performed at $30^{\circ} \mathrm{C}$. To determine the effect of temperature on the enzymatic activity, samples were incubated at temperatures ranging from 10 to $70^{\circ} \mathrm{C}$ for $1 \mathrm{~h}$. Hydrolysis of CS, CP, CM, DZ, DY, EP, FA, MPT, and PT were measured by changes in absorbance at $214 \mathrm{~nm}$ by HPLC. Enzyme sample $(50 \mu \mathrm{L})$ was added to an assay mixture containing $700 \mu \mathrm{L} 200 \mathrm{mM}$ phosphate-buffer saline (PBS, pH 6.5) and $250 \mu \mathrm{L}$ CS, CP, CM, DZ, DY, EP, FA, MPT, and PT (100 mg/L). All assays were performed in triplicate. 


\section{Active site prediction analyses of OpdC enzyme}

The site directed mutagenesis technique and bioinformatic tools were used to confirm the potential active site of the OpdC enzyme. To confirm location of the catalytic sites of OpdC, amino acid exchanges were introduced at position 116 (serine to alanine) of OpdC was performed using oligonucleotide primer: 5'TCTTGCCGGGTTTICGGCTGG CGG CCACG-3' (sense), 5'-CGTGGCCGC CAGCCG AAA ACCCGGCAAGA-3' (antisense) $5^{\prime}$. The positions of the mutated codons are underlined. The $50 \mu \mathrm{L}$ of reaction mixtures contained $1 \mu \mathrm{L}$ of the pET-32a(+)/opdC DNA ( $80 \mathrm{ng} / \mu \mathrm{L}), 4 \mu \mathrm{L}$ of $10 \rho$ mol of each primer, $5 \mu \mathrm{L}$ of $2 \mathrm{mM}$ dNTP mixture, and $5 \mu \mathrm{L}$ of 10x Pfu DNA polymerase buffer, which, in turn, contained $20 \mathrm{mM} \mathrm{MgSO}_{4}$, and $2.5 \mathrm{U}$ of Pfu DNA polymerase (purchased from Stratagene; La Jolla, CA, USA). The PCR products were incubated on ice for $5 \mathrm{~min}$, and $1 \mu \mathrm{L}$ of $D p n$ restriction enzyme $(10 \mathrm{U} / \mu \mathrm{L})$ was added. Then, the mixture was incubated for $1 \mathrm{~h}$ at $37^{\circ} \mathrm{C}$. The Dpnl-treated plasmids were then transformed into E. coli DH5a according to the manufacturer's specifications. The site-directed mutagenesis procedure was adapted from as described Haque et al. (2018). The predictive active site of the OpdC protein was investigated using sequential application of several bioninformatic tools. At first, the modeling of the OpdC protein was built in Swiss modeling (https://swissmodel.expasy.org/) to create the protein data bank (pdb) file of the OpdCbased on an esterase protein from the protein data bank (accession number: 4bzw). After that 4 bzw was used to get an alignment with OpdC with the help of 'Clustal Omega' (https://www.ebi.ac.uk/Tools/msa/clustalo/), then the clustal file was selected and used to find a secondary similarity analysis between the OpdC and 4bzw using 'ESPrit3' (http://espript.ibcp.fr/ESPript/ESPript/).

\section{Results}

\section{Identification and resistance of the strain WCP931 under acidic and artificial gastric acidic conditions}

The levels of 16S rRNA similarity between the WCP931 strain and reference LAB were 85.4 to $99.5 \%$ and the phylogenetic study clearly demonstrated that strain WCP931 strain was closely related to Lactobacillus sp.. Finally, the CP degrading strain was named Lactobacillus plantarum WCP931 (supplementary Fig. S1).

The survival rates of L. plantarum WCP931 when cultured under acidic and artificial gastric acidic conditions are shown in Fig. 1. Moderate survival rates are observed for the CP-degrading strain WCP931 with $86 \%$ (acidic condition) and $51 \%$ (artificial gastric acidic condition) at $\mathrm{pH} 2.0,95 \%$ (acidic) and $84 \%$ (artificial gastric acidic) at pH 2.5, and 99\% (acidic) and 96\% (artificial gastric acidic) at pH 2.5 after 3 h, respectively.

\section{Degradation of CP by the strain WCP931 in liquid culture}

The cell growth response and the degradation pattern of CP in the strain of WCP931 are shown in Fig. 2. The strains grown markedly increased until 1 day (OD 0.85), then decreased at 2 days, and after these grown slowly at 6 days (OD 0.94) during incubation, respectively. However, LAB strain WCP931 exhibited 
an initial rapid degradation of CP of approximately $66 \mathrm{mg} / \mathrm{L}$ during first 3 days of incubation. After these $\mathrm{CP}$ was degraded slowly and maximum degradation was found $87 \mathrm{mg} / \mathrm{L}$ at 9 days of incubation (Fig. 2A). The strain WCP931 was able to degrade CP to DETP and TCP and utilized DETP as the sole source of carbon and phosphorus. All OP insecticides tested in the cross feeding experiment were degraded by the WCP931 strains. All tested OP insecticides have DEPT as side chains (CP, CM, DZ, MPT, and PT) and had no DEPT as side chains (CS, DF, EP, and FA). Except DF, other eight OP insecticides (including CS, CP, $\mathrm{CM}, \mathrm{DZ}, \mathrm{EP}, \mathrm{FA}, \mathrm{MPT}$, and PT) hydrolyzed at a phosphoester bond by the strains of WCP931. At 9 days, the strain WCP931 attained 72 to $88 \%$ degradation of CP, CM, DZ, MPT, and PT, respectively (Fig. 2B).

\section{Sequence analysis of the opdC gene and OpdC protein}

PCR amplification of the total DNA from L. plantarum WCP931 with specific primers produced amplification product of about $1.5 \mathrm{~kb}$. After sequencing, total $1500 \mathrm{bp}$ nucleotide sequence is found in the open reading frame of opdC of L. plantarum WCP931. The open reading frame of opdC starts with an ATG start codon and TAA Ochre stop codon (Fig. 3). The gene product is predicted to contain 276 amino acids with a predicted molecular mass of $31 \mathrm{kDa}$, respectively (http://web.expasy.org/compute_pi/). Analysis of the amino acid sequence with the program PSORT (http://www.cbs.dtu.dk/services/SignalP/) revealed no potential signal sequence. The calculated $\mathrm{p} /$ of $\mathrm{OpdC}$ is 5.18 .

The amino acid sequence GFSAG, starting at residue 116 for the OpdC (Fig. 3 and supplementary Fig. S2), fits the Gly-X-Ser-X-Gly motif found in most bacterial and eukaryotic serine hydrolases, such as lipase, esterase, and serine proteinase as well as in $\beta$-lactamase (Bornscheuer 2002; Brenner 1988; Ouyang et al. 2013). A phylogenetic tree containing the esterolytic and lipolytic proteins showed that the OpdC protein does not belong to group I, II, III or IV (Fig. 4). This separation of OpdC from the known esterolytic and lipolytic proteins suggests that OpdC represent a new type of esterase.

\section{Degradation of CP by the clone in liquid culture}

The degradation patterns of CP of the clone pGCY300 (opdC) are shown in Fig. 5. The CP and TCP with $R_{f}$ values of 0.57 and 0.66 , respectively were detected in samples drawn at $0,1,3,6$, and 9 days (Fig. 5A). The clone decomposed markedly until 2 days $(78 \mathrm{mg} / \mathrm{L})$, then decreased markedly at 6 days $(24 \mathrm{mg} / \mathrm{L})$, and after these grown slowly until 9 days during incubation. On the other hand, during 3 days, the clone exhibited slowly increment of TCP of approximately $32 \mathrm{mg} / \mathrm{L}$ of TCP at 3 days and after these increased markedly at 6 days (68 mg/L) (Fig. 5B). The nine OP insecticides (such as CS, CP, CM, DZ, EP, FA, MPT, and $\mathrm{PT}$ ) were disintegrated by the recombinant $E$. coli with opdC gene. The recombinant cells fetched 46 to $90 \%$ degradation of $\mathrm{CP}, \mathrm{CM}, \mathrm{DZ}, \mathrm{FA}, \mathrm{MPT}$, and PT at $37^{\circ} \mathrm{C}$ for 9 days, respectively (Fig. $5 \mathrm{C}$ ).

\section{Purification and characterization of the OpdC protein}

OpdC protein was purified from E. coliBL21 (DE3) overproducing OpdC using column filtration techniques. Protein fractions were analyzed by SDS-PAGE, and one protein band (31 kDa) was present after the final purification step (Fig. 6A). The effect of $\mathrm{pH}$ on the ability of OpdC to hydrolyze $\rho \mathrm{NPB}$ was 
determined at $40{ }^{\circ} \mathrm{C}$ with various buffers ranging from $\mathrm{pH} 3.0$ to 11.0 . The maximum activity of OpdC was observed at $\mathrm{pH}$ (Fig. 6B). The optimal temperature for OpdC hydrolysis of $\rho$ NPB was determined at $\mathrm{pH} 6$ by measuring the activity across a temperature range. The OpdC activity was observed maximum at $30^{\circ} \mathrm{C}$ (Figs. 6C). In fact, nine OP insecticides were decomposed by OpdC (Fig. 6D). Except for DF, eight OP insecticides (including CS, CP, CM, DZ, EP, FA, MPT, and PT) hydrolyzed at a phosphoester bond by the OpdC protein. Especially, the higher enzyme activity was observed towards the $C P, C M, D Z, M P T$, and PT by OpdC protein.

\section{Identification of residues essential for enzyme activity of OpdC}

Most lipases and carboxyl esterases have the consensus sequence motif Gly-X-Ser-X-Gly that includes the active site serine. Analysis of the deduced amino acid sequences of OpdC showed a potential serine hydrolase motif such as G-F-S116-A-G of OpdC. To determine whether Ser116 were involved in catalytic esterase action, there were replaced by site-direct mutagenesis and the mutant proteins were expressed in E. coli and purified. The purified OpdC enzyme showed $78 \%$ degradation rate of $\mathrm{CP}$, while the mutant OpdC had no enzymatic activity towards $\rho$ NPB and CP (Table 1). The structure of OpdC is comprised by $31.5 \%$ of a-helix and $21 \%$ of $\beta$ strand, respectively. In particular, the G-F-S-A-G motif for OpdC was found in the $\beta 5$ and $a 3$ helix of the predicted structures (supplementary Fig. S2). By using the scoring option found in 'ESPrit3' (http://espript.ibcp.fr/ESPript/ESPript/) and data found on Metapocket2.0 (projects.biotec.tu-dresden.de/metapocket/) the highest probable active sites was marked as seen in Fig. 7. The predicted OpdC structure revealed that the active site of this enzyme was located in the known architecture of the hydrolases (Fig. 7A). The key nucleophile, Ser116, forms part of a predicted catalytic triad with Ala116, Gly118, and Phe114 for the OpdC protein. Importantly, the OpdC enzyme had shown average $18.59 \%$ amino acid identity with Opd group (OpdA, OpdB, OpdD, and OpdE) enzymes of lactic acid bacteria. In particular, it had shared $55 \%$ homology with their nearest OpdD enzyme of $L$. sakei WCP904 (Haque et al., 2018). These results suggested that the OpdC indicates the existence of a new LAB esterase/opdase group.

\section{Discussion}

The isolated L. plantarum WCP931 was screened for its ability to degrade OP insecticides. L. plantarum is a lactic acid bacterium found in many habitats, including meat and dairy products, plant and vegetable fermentations, and the gastrointestinal and urogenital tracts. This strain has been attributed probiotic activities in humans and animals (Cebeci and Gurakan 2003; Kim et al. 2020). The bacterium WCP931 is unusual as it has been shown to hydrolyze CP and utilizes part of the compound (DEPT) as its sole source of carbon when cultured in M9 or 1/25 MRS medium. The evidence from the studies with TLC and HPLC analysis for CP supports the proposed pathway. A higher bacterial population of L. plantarum WCP931 was observed in 1/25 MRS medium along with CP degradation. Moreover, the isolated bacterium WCP931 exhibited versatility in utilizing dimethyl compounds such as MPT, and diethyl compounds such as CP, CM, DZ, and PT as its carbon source, which suggests that strain WCP931 has potential role for the decontamination of the $\mathrm{OP}$ insecticides. The bacterial degradation and 
detoxification of insecticides is mainly depending on the presence of degradative enzymes (Singh et al. 2006). Thus, the isolate WCP931 possess a great potential to provide a versatile gene or enzymes system for the remediation of highly toxic OP insecticides, since it showed broad specificity against a range of OP compounds. As consequence, we isolated OP insecticides degrading gene (opdC) from the $L$. plantarum WCP931. The recombinant $E$. coli harboring opdC gene was capable of degrading CP. It could utilize the $\mathrm{CP}$ as the sole carbon source when grown in M9 medium that was supplemented with $\mathrm{CP}$ instead of glucose. In particular, it had depleted the CP concentration to 77\% in M9 medium after 6 days. In previous study, the $E$. coli harboring opdD gene depleted CP concentration to $73 \%$, in $\mathrm{M} 9$ medium after 6 days (Haque et al. 2018), while the E. coli harboring opdB gene depleted the CP concentration to $67 \%$ in M9 medium after 6 days (Islam et al. 2010). Therefore, the CP degrading ability of opdC clone is stronger than those reported opdB (Islam et al. 2010) and opdD clones (Haque et al. 2018).

Three OP hydrolase genes namely opd, $m p d$, and ophc2 have been reported yet. Among them, the opd gene is widely distributed in nature and isolated from different species (Chaudhry et al. 1988; Haque et al. 2018; Islam et al. 2010; Serdar et al. 1982; Siddavattam et al. 2003). The reported opd genes were belongs to chromosome (Mulbry et al. 1987; Serdar et al. 1982) or plasmid (Horne et al. 2002) of the isolated strains. However, yet no study reported the opd gene from the super probiotic L. plantarum. Therefore, the cloned and functionally expressed chromosome based opdC gene from the L. plantarum WCP931 increasing the diversity of the hosts of OP hydrolases. Despite the lack of any signal sequences in the N-terminal region of the OpdC, the $E$. coli cells secreted those enzymes in the CP mixed liquid culture, consequently, the recombinant $E$. coli harboring the opdC genes was capable of degrading OP insecticides.

The nonclassical secreted proteins often seem to have a cytoplasmic function as well as extracellular functional role (Bendtsen et al. 2005). In addition, carbohydrate and protein metabolism related proteins were identified as extracellular, although none of these proteins have a signal peptide (Antelmann et al., 2001; Vitikainen et al., 2004). Since insecticides and their hydrolysis products were extracted from culture medium, therefore, it is assumed that the OpdC enzymes used non classical pathways to display its extracellular activities. In fact, OP are hydrophobic in nature, thus, compounds in the culture medium are in equilibrium with compounds inside the bacterial cell. Therefore, hydrolysis could be taking place inside the cell, followed by release of the hydrolysis product into the culture medium. As a matter of fact, finding products in the culture medium does not rule out the possibility that hydrolysis takes place inside the cell.

The OpdC enzyme hydrolyzed range of OP insecticides containing a P-O bond and P-S bond, indicating that the recombinant OpdC has broad substrate specificity. A similar result was obtained by some previous reports (Li et al. 2007; Haque et al. 2018; Horne et al. 2002; Islam et al. 2010; Yang et al. 2006). However, relative activity of the OpdC enzyme against the P-O bond insecticides was much higher than P$S$ bond insecticides, which is consistent with the previously reported OpdB and OpdD enzymes character (Islam et al. 2010; Haque et al. 2018). However, minor variations of relative substrate activities were observed for the OpdC enzyme than those reported OpdB, OpdA, OpdE enzymes. Thus, the OpdC hydrolysis activity depends on the molecular structure of insecticides used in this study. 
Temperature had influenced the OpdC activity. The optimum pH of OpdD (6.0) from L. sakei WCP904 (Haque et al. 2018) and OpdB from L. brevis WCP902 (6.0) (Islam et al. 2010) and was lower than those OpdB from Pesudomonas sp. BP3 (8.0) (Singh et al. 2006). The L. plantarum is known to be able to adapt to stressful environments such as those in the gastrointestinal tract with a low pH or high salt content. In order to survive in acidic environments, this bacterium uses the $F_{0} F_{1}-A T P a s e$ and sodiumproton pumps to help regulate and maintain the intracellular pH (Kleerebezem, et al. 2003). In fact, kimchi fermentation involving $L A B$ is conducted at acidic $\mathrm{pH}$. Among the $L A B$, the L. plantarum is quite predominant when $\mathrm{pH}$ is lowered and responsible for acidifying of the kimchi. Therefore, the OpdC maximum activity obtained at acidic $\mathrm{pH} 5 \sim 6$ is quite logic/consistent. However, OP insecticides are stable in mild acidic to neutral pH and easily decomposed in alkine pH (Lee and Lee 1997). As consequence, the degradation rate of $\mathrm{CP}$ in acidic soils was slower than in neutral and alkaline soils ( $\mathrm{Li}$ et al. 2007; Yang et al. 2006). Importantly, optimum temperature $\left(40^{\circ} \mathrm{C}\right)$ for $\mathrm{OpdC}$ was similar with that recorded for OP hydrolase (OpdB) of L. brevis WCP902 (40 $\left.{ }^{\circ} \mathrm{C}\right)$ (Islam et al. 2010), but higher than those were recorded for OpdD of $L$. sakei WCP904 $\left(30^{\circ} \mathrm{C}\right)$ (Haque et al. 2018).

The OpdC protein has a sequence Gly-X-Ser-X-Gly motif and catalytic active site of serine residues. Actually, this motif and active site is found in most bacterial and eukaryotic serine hydrolases, such as lipase, esterase, and serine proteinase as well as in $\beta$-lactamase (Bornscheuer 2002; Brenner 1988; Ouyang et al. 2013). However, the phylogenetic tree analysis of OpdC protein showed that it does not belong to the known families of esterolytic and lipolytic proteins (groups I, II, III, IV or even new group of soil metagenome), indicating the existence of a new LAB esterase/opdase group, represented by OpdC (Fig. 4). Importantly, our previous reported OpdB and OpdD enzyme had shown the Gly-X-Ser-X-Gly motif and catalytic active site of serine residues. As consequence, we are going to propose a new esterase group (LAB-opd esterase) that is summarized by OP hydrolase genes from LABs strain isolated during kimchi fermentation.

As seen in Fig. 5 , the a-helix, $\beta$ sheet, random coil, and $\beta$ turn were observed in both structure of OpdC enzymes and were matched with the catalytic motif G-X-S-X-G of OpdC and OpdD enzymes (Islam et al. 2010; Haque et al. 2018). When the Ser116 residue was replaced by Ala, the mutant OpdC enzymes had no enzymatic activity towards the $\rho$ NPB and CP. As consequence, the mutation at Ser116 of OpdC has massively reorganized the structural conformation than the native OpdC protein respectively (Fig. 7B). The amino acid residues Ser ${ }^{10}$-Asp ${ }^{154}$-His ${ }^{157}$ are involved in the catalytic active site of $E$. colithioesterase I/protease I (Lee et al. 2006), therefore, the predicted structure of OpdC is partially shared the structure of esterase as well as new LAB-Opd hydrolase. As the results, the classification of the esterase is expanded in to LAB-Opd group (Islam et al. 2010; Haque et al. 2018) where OpdC are included in this study.

With regard to the safety of insecticide in kimchi, we had concluded that the fermented kimchi meets the minimal residue criteria for food safety due to OPs degradation by kimchi microorganisms such as $L$. mesenteriodes, L. brevis, L. plantarum, and L. sakei (Cho et al., 2009a). The present study suggested that 
the genes opdC in L. plantarum WCP931 along with opdB in L. bevis WCP902 and opdD in L. sakei WCP904 play role to degrades the OP insecticides during kimchi fermentation.

\section{Abbreviations}

LAB: Lactic acid bacteria; OP: Organophosphorus; CP: Chlorpyrifos; CS: cadusafos; CM; comnaphos; DZ: diazinon; DF: dyfonate; EP: ethoprophos; FA: fenamiphos; MPT: methylparathion; PT: parathion; TCP: 3,5,6-trichloro-2-pyridinol; DETP: Diethylthiophosphate; TLC: Thin layer chromatogram; HPLC: High press liquid chromatogram.

\section{Declarations}

\section{Ethics approval and consent to participate}

In current research, the article doesn't contain any data collected from humans or animals and also there was no involvement of human participants and doesn't belongs to any health was related outcomes and articles.

\section{Consent for publication}

This research article entitled as "Cloning, expression, and functional characterization of an organophosphates insecticides degrading gene (opdC) from a potential probiotic Lactobacillus plantarum WCP931" an original work was carried out by authors: All authors approve of its submission to as AMB express. It is not under consideration by another journal at the same time as AMB express. I am the author responsible for the submission of this article and I accept the conditions of submission and the Springer Open Copyright and License Agreement.

\section{Availability of data and material}

The datasets used and analyzed during the current study are available from the corresponding author on reasonable request.

\section{Competing interests}

As a corresponding author, I confirm that I have read Springer Open's guidance on competing interests and have included a statement indicating that none of the authors have any competing interests in the paper.

\section{Funding}

This work was supported by the research invigoration program of 2020 Gyeongnam National University of Science and Technology.

\section{Authors' contributions}


$\mathrm{KMC}$ conceived and designed the experiments. $\mathrm{KMC}, \mathrm{MAH}$, and $\mathrm{JHL}$ interpreted the data and wrote the manuscript. HYL, DYC, and JEH performed the experiments and analyzed the data. All authors read and approved the final manuscript.

\section{Acknowledgements}

The authors acknowledge to Department of Food Science, Gyeongnam National University of Science and Technology for providing lab facility to carry out this work.

\section{Author details}

${ }^{1}$ Department of Biochemistry \& Molecular Biology, Hajee Mohammad Danesh Science \& Technology University, Dinajpur 5200, Bangladesh. ${ }^{2}$ Department of Food Science, Gyeongnam National University of Science and Technology, Jinju 52725, Republic of Korea. ${ }^{3}$ Department of Life Resources Industry, Dong-A University, Busan 49315, Republic of Korea. ${ }^{4}$ Department of Research \& Development, Jinju Bioindustry Foundation, Jinju 52839, Republic of Korea.

\section{References}

Ahmed F, lqbal S, Anwar S, Afzal M, Islam E, Mustafa T, Khan QM (2012) Enhanced remediation of chlorpyrifos from soil using rye grass (Lollium multiflorum) and chlorpyrifos-degrading bacterium Bacillus pumilus C2A1. J Hazard Mater 237-238:110-115.

Antelmann H, Tjalsma H, Voigt B, Ohlmeier S, Bron S, van Digl JM, Hecker M (2001) A proteomic view on genome-based signal peptide predictions. Genome Res 11:1484-502.

Bendtsen DJ, Kiemer L, Fausboll A, Brunak S (2005) Non-classical protein secretion in bacteria. BMC Microbiol 5:58-70.

Brenner S (1998) The molecular evolution of genes and proteins: a tale of two serines. Nature 334:528530 .

Bornscheuer UT (2002) Microbial carboxyl esterase: classification, properties and application in biocatalysis. FEMS Mcirobiol Rev 26:73-81.

Cebeci A, Gurakan C (2003) Properties of potential probiotic Lactobacillus plantarum strains. Food Microbiol 20:511-518.

Chaudhry GR, Ali AN, Wheeler WB (1988) Isolation of a methyl perathion-degrading Pseudomonas sp. that possesses DNA homologuous to the opd gene from a Flavobacterium sp.. Appl Environ Microbiol 54:288-293.

Cho KM, Math RK, Islam SMA, Lim WJ, Hong SY, Kim JM, Yun MG, Cho JJ, Yun HD (2009a) Biodegradation of chlorpyrifos by lactic acid bacteria during Kimchi fermentation. J Agric Food Chem 
57(5):1882-1889.

Cho KM, Math RK, Islam SMA, Lim WJ, Hong SY, Kim JM, Yun MG, Cho JJ, Yun HD (2009b) Novel multiplex PCR for the detection of lactic acid bacteria during kimchi fermentation. Mol Cell Probes 23:9094.

Cho KM (2008) Characterization of potential probiotics Bacillus subtilis CS90 from soybean paste (doenjang) and its antimicrobial activity against food-borne pathogens. J Appl Biol Chem 51:285-291.

Ducrotté P, Sawant P, Jayanthi V (2012) Clinical trial: Lactobacillus plantarum 299v (DSM 9843) improves symptoms of irritable bowel syndrome. World J Gastroenterol 18(30):4012-4018.

Getzin LW (1981) Degradation of chlorpyrifos in soil: influence of autoclaving, soil moisture, and temperature. J Econ Entomol 74:58-162.

Haque MA, Hong SY, Hwang CE, Kim SC, Cho KM (2018) Cloning of an organophosphorus hydrolase (opdD) gene of Lactobacillus sakei WCP904 isolated from chlorpyrifos impregnated kimchi and hydrolysis activities of its gene product for organophosphorus pesticides. Appl Biol Chem 61(6):643-651.

Harishankar MK, Sasikala C, Ramya M (2013) Efficiency of the intestinal bacteria in the degradation of the toxic pesticide, chlorpyrifos. 3 Biotech 3:137-142.

Hwang KW, Moon MK (2018) Translocation of chlorpyrifos residue from soil to Korean cabbage. Appl Biol Chem 61:145-152.

Huete-Soto A, Castillo-González H, Masís-Mora M, Chin-Pampillo JS, Rodríguez-Rodríguez CE (2017) Effects of oxytetracycline on the performance and activity of biomixtures: Removal of herbicides and mineralization of chlorpyrifos. J Hazard Mater 321:1-8.

Horne I, Sutherland TD, Harcourt RL, Russell RJ, Oakeshott JG (2002) Identification of an opd (organophosphate degradation) gene in an Agrobacterium isolate. Appl Environ Microbiol 68:3371-3376.

Islam SMA, Math RK, Cho KM, Lim WJ, Hong SY, Kim JM, Yun MG, Cho JJ, Yun HD Organophosphorus hydrolase (OpdB) of Lactobacillus brevis WCP902 from kimchi is able to degrade organophosphorus pesticides, J Agric Food Chem 58:5380-5386.

Johansson ML, Nobaek S, Berggren A, Nyman M, Björck I, Ahrné S, Jeppsson B, Molin G (1998) Survival of Lactobacillus plantarum DSM $9843(299 \mathrm{v})$, and effect on the short-chain fatty acid content of faeces after ingestion of a rose-hip drink with fermented oats. Int J Food Microbiol 42:29-38.

Kademi A, Ait-Abdelkader N, Fakhreddine L, Baratti JC (1999) Thermostable esterase activity from newly isolated moderate thermophilic bacteria strains. Enzyme Microb Technol 24:332-338. 
Kim B, Seo WT, Kim MG, Yun HD, Cho KM (2012) Metagenomic lactic acid bacterial diversity during mulkimchi fermentation based on 16S rRNA sequence. J Korean Soc Appl Biol Chem 55:787-792.

Kim DH, Kim S, Ahn JB, Kim JH, Ma HW, Seo DH, Che X, Park KC, Yong JJ, Kim SY, Lee HC, Lee J-Y, Kim TI, Kim WH, Kim SW (2020) Lactobacillus plantarum CBT LP3 ameliorates colitis via modulating T cells in mice. Int J Med Microbiol 310:151391.

Kleerebezem M, Boekhorst J, van Kranenburg R, Molenaar D, Kuipers OP, Leer R, Tarchini R, Peters SA, Sandbrink HM, Fiers MWEJ, Stiekema W, Lankhorst RMK, Bron PA, Hoffer SM, Groot MNN, Kerkhoven R, de Vries M, Ursing B, de Vos WM, Siezen RJ (1995) Complete genome sequence of Lactobacillus plantarum WCFS1. PNAS 100:1990-1995.

Lee MG, Lee SR (1997) Elimination of insecticide EPN residues during rice cooking and kimchi preparation. Food Biotechnol 6:39-43.

Lee LC, Lee YL, Leu RJ, Shaw JF (2006) Functional role of catalytic triad and oxyanion hole-forming residues on enzyme activity of Escherichia coli thioesterase I/protease I/ phospholipase L1. Biochem J 397:69-76.

Li X, He J, Li S (2007) Isolation of a chlorpyrifos-degrading bacterium, Sphingomonas sp. strain Dsp-2, and cloning of the mpd gene. Res Microbiol 158:143-149.

Mack DR, Ahrne S, Hyde L, Wei S, Hollingsworth MA (2003) Extracellular MUC3 mucin secretion follows adherence of Lactobacillus strains to intestinal epithelial cells in vitro. Gut 52:827-833.

Mulbry WW, Kearney PC, Nelson JO, Karns JS (1987) Physical comparison of parathion hydrolase plasmids from Pseudomonas diminuta and Favobacterium sp. Plasmid 18:173-177.

Ouyang LM, Liu JY, Qiao M, Xu JH (2013) Isolation and biochemical characterization of two novel metagenome-derived esterases. Appl Biochem Biotech 169:15-28.

Park WS, Moon SW, Lee MK, Ahn BH, Koo YJ, Kim KH (1996) Comparison of fermentation characteristics of the main types of Chinese cabbage kimchi. Food Biotechnol 5:128-135.

Singh BK, Walker A, Wright DJ (2006) Bioremedial potential of fenamiphos and chlorpyrifos degrading isolates: Influence of different environmental conditions. Soil Biol Biochem 38:2682-2693.

Serdar CM, Gibson DT, Munnecke DM, Lancaster JH (1982) Plasmid involvement in parathion hydrolysis by Pseudomonas diminuta. Appl Environ Microbiol 44:246-249.

Siddavattam D, Khajamohiddin S, Manavathi B, Pakala SB, Merrick M (2003) Transposon-like organization of the plasmid-borne organophosphate degradation (opd) gene cluster found in Flavobacterium sp.. Appl Environ Microbiol 69:2533-2539. 
Siroli L, Patrignani F, Serrazanetti DI, Tabanell G, Montanari C, Gardini F, Lanciotti R (2015) Lactic acid bacteria and natural antimicrobials to improve the safety and self-life of minimally processed sliced apples and lamb's lettuce. Food microbiol 47:74-84.

Tariq MI, Afzal S, Hussian I, Sultana N (2007) Pesticide exposure in Pakistan: a review. Environ. Int. 33:1107-1122.

Vitikainen M, Lappalainen I, Seppala R, Antelmann H, Boer H, Taira S, Savilahti H, Hecker M, Vihinen M, Sarvas M, Kontinen VP (2004) Structure-function analysis of PrsA reveals roles for the parvulin-like and flanking $\mathrm{N}$-and C-terminal domains in protein folding and secretion in Bacillus subtilis. J Biol Chem 279:19302-19314.

Yang C, Liu N, Guo X, Qiao C (2006) Cloning of $m p d$ gene from a chlorpyrifos-degrading bacterium and use of this strain in bioremediation of contaminated soil. FEMS Microbiol Lett 265:118-125.

Yu YL, Fang H, Wang X, Wu XM, Shan M, Yu JQ (2006) Characterization of a fungal strain capable of degrading chlorpyrifos and its used in detoxification of the insecticide on vegetables. Biodegradation 17:487-494.

Zhang YH, Xu D, Liu JQ, Zhao XH (2014) Enhanced degradation of five organophosphorus pesticides in skimmed milk by lactic bacteria and its potential relationship with phosphatase production. Food Chem 164:173-178.

\section{Table}

Table 1. Esterase and orangophosphorus (OP) hydrolase activities for the hydrolysis of $\rho$-nitrophenyl butyrate ( $\rho$-NPB) and chlorpyrifos (CP) by the OpdC and mutant OpdC enyzme

\begin{tabular}{ll} 
Proteins & Esterase activity ${ }^{\mathrm{a}}(\mathrm{U} / \mathrm{mg}) / \mathrm{CP}$ degradation degree ${ }^{\mathrm{b}}(\%)$ \\
\hline OpdC & $397 \pm 15.88^{\mathrm{c}} / 78$ \\
\hline OpdCM & $<0.01 / 2$
\end{tabular}

a Esterase activity is indicated the micromoles of $\rho$-NPB hydrolyzed $\mathrm{min} / \mathrm{mg}$.

${ }^{\mathrm{b}}$ The OpdC and OpdCM activities were assayed with $\mathrm{CP}$ as substrate at $\mathrm{pH} 6.0$ and $40{ }^{\circ} \mathrm{C}$ for $12 \mathrm{~h}$, respectively.

${ }^{c}$ Values indicate the means of three replications. The standard errors were within $5 \%$ of the mean.

\section{Figures}



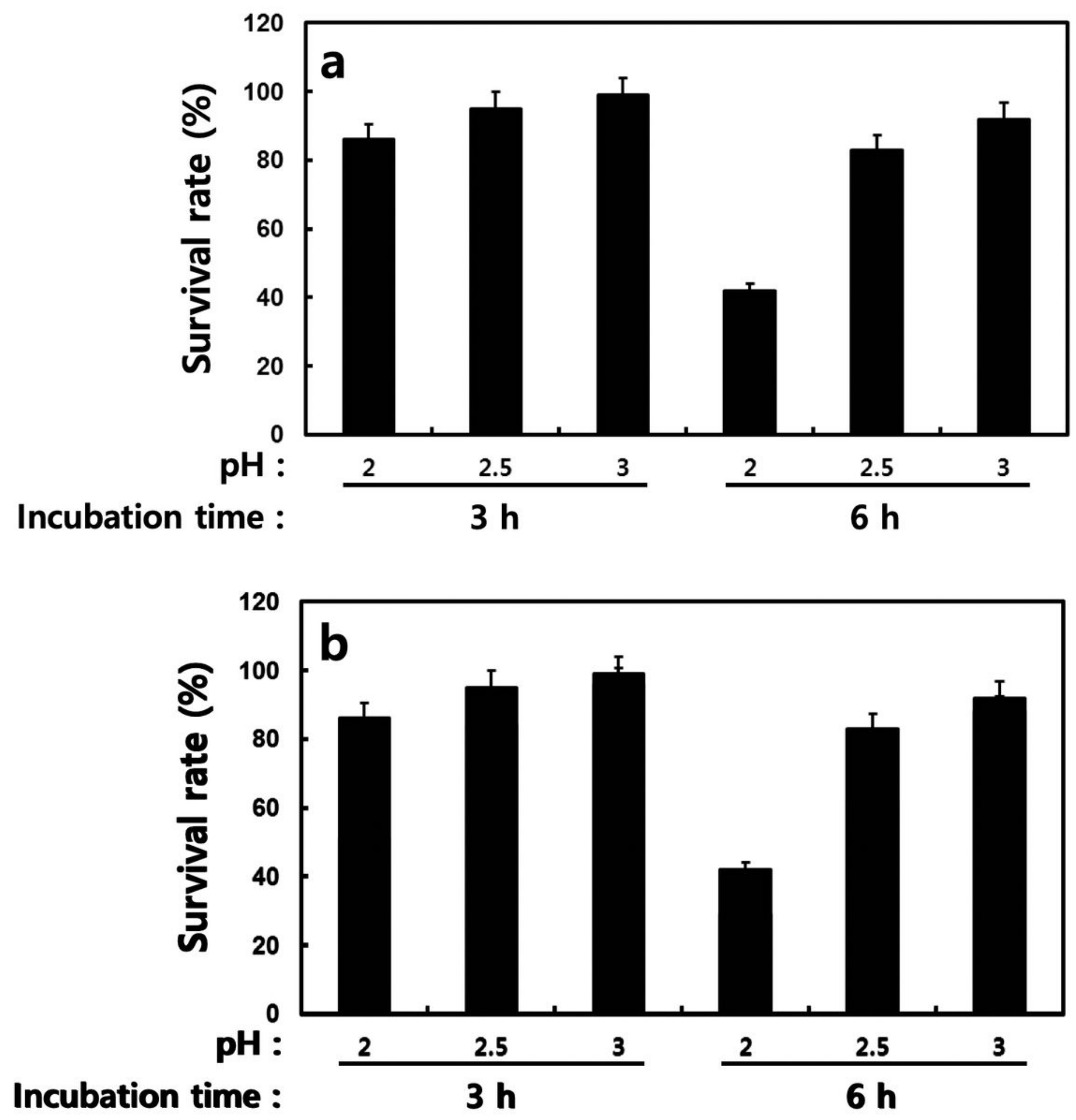

Figure 1

a Survival rates of L. plantarum WCP931 under acidic conditions and b survival rates of L. plantarum WCP931 under artificial gastric acidic conditions at pH 2.0, 2.5, and 3.0 after 3 and $6 \mathrm{~h}$ of incubation. L. plantarum WCP931 was tested in triplicate for its tolerance in acidified and artificial gastric acidified MRS. The standard errors were within $5 \%$ of the mean. 

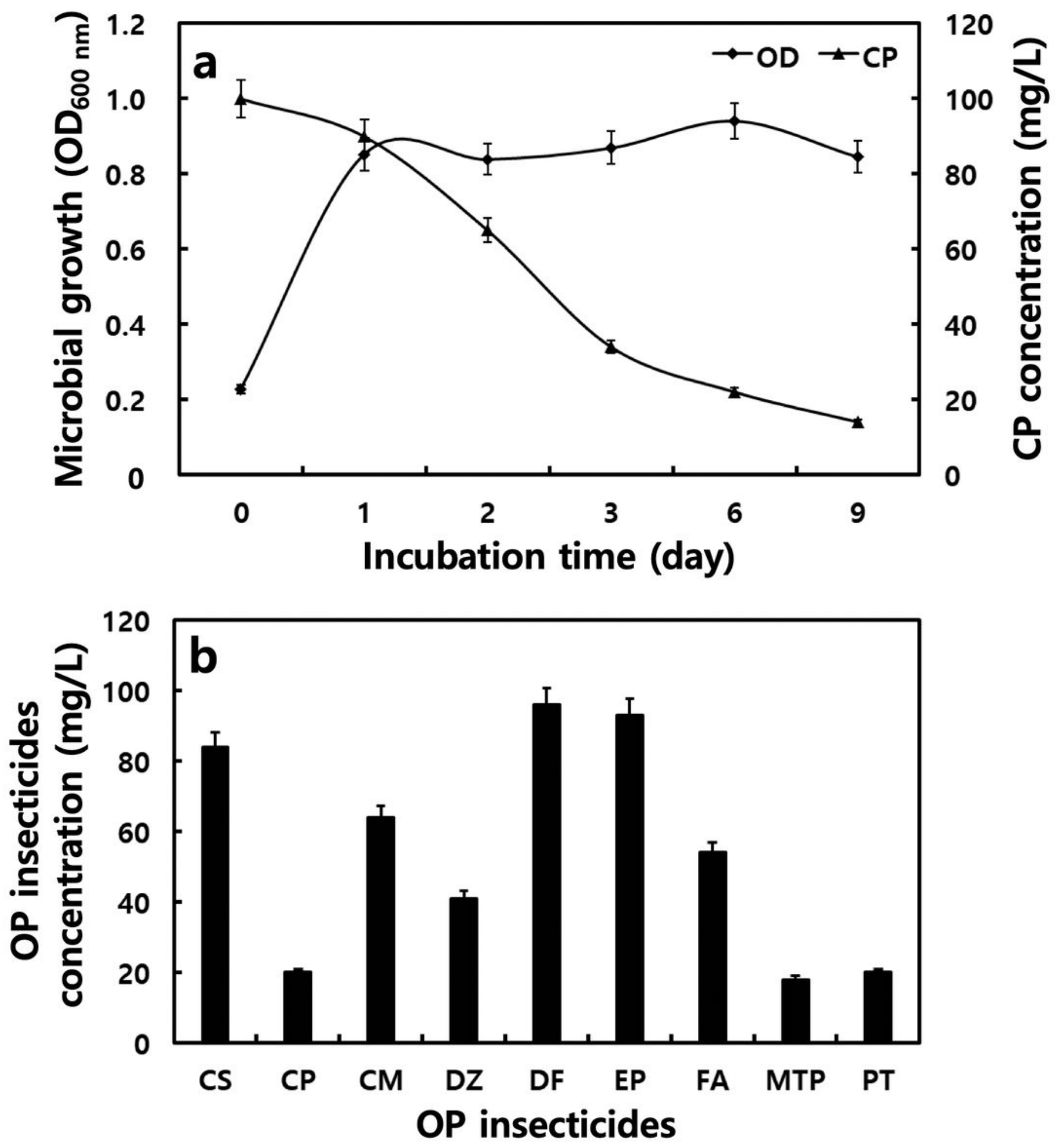

Figure 2

a Cell growth response and $b$ CP degradation pattern of L. plantarum WCP931 in 1/25 MRS containing $100 \mathrm{mg} / \mathrm{L}$ of CP for 9 days. The standard errors were within $5 \%$ of the mean. 
CTGGGTTTGTGGCGTGTGCTCCAATAAGACCACCCCGCGCCCCTTAACGCTGTAAACTAG

61 GCCGTCTTTGGCTAGTTGTGCGATTGCCTTACGAACAGCATAGCGACTGCTATCAAATTC

121 TGTAATTAATTCGTCTTCAATGGGTAATCGCATCTTAACGCTGTAGTGTCCCGTGAGAAT

181 GCGGTCCTTTAAAACGTGATAGATGTCGCTGAATGTTTGTTTCCCCATTTTAATACCCCC

241 GCTCATCATATAATTAATTTAATTATAGCAAATAATAGTCATTAGCGAGTAAACAAGCGA

301 ATAAATATCGATATTTATTCGAATAAAAATTGACAAGCAATCATGTGACCTACTATAATG

361

1 AAAGCGAAATCAAGTCGGTAATACGGGAGTAGGAGGGGGAACATATGCAAGTTGAACAGC

421

6

481

26

541

46

601

66

661

86

721

106

781

126

841

146

901

166

961

186

1021

206

1081

226

1141

246

1201

266

1261

1321

1381

1441

GCACATTAAATACTGCGGCACACCCATTTCAGATCACGGCGTATTGGTTAGACCAAATTA $\begin{array}{llllllllllllllllllll}R & T & L & N & T & A & A & H & P & F & Q & I & T & A & Y & W & L & D & Q & I\end{array}$ GTGATTTTGAAACAGCTGTTGATTATCCAATCATGATTATCTGCCCGGGAGGTGGCTTTA $\begin{array}{llllllllllllllllllll}S & D & F & E & T & A & V & D & Y & P & I & M & I & I & C & P & G & G & G & F\end{array}$ CTTATCATTCTGGGCGGGAAGAAGCGCCAATTGCAACCCGGATGATGGCCGCCGGAATGC $\begin{array}{llllllllllllllllllll}T & Y & H & S & G & R & E & E & A & P & I & A & T & R & M & M & A & A & G & M\end{array}$ ATACGGTGGTCTTGAATTACCAATTAATTGTGGGAGATCAGTCCGTCTATCCTTGGGCGT $\begin{array}{llllllllllllllllllll}H & \mathrm{~T} & \mathrm{~V} & \mathrm{~V} & \mathrm{~L} & \mathrm{~N} & \mathrm{Y} & \mathrm{Q} & \mathrm{L} & \mathrm{I} & \mathrm{V} & \mathrm{G} & \mathrm{D} & \mathrm{Q} & \mathrm{S} & \mathrm{V} & \mathrm{Y} & \mathrm{P} & \mathrm{W} & \mathrm{A}\end{array}$ TGCAGCAATTAGGTGCAACAATTGATTGGATTACGACCCAGGCGTCCGCGCACCATGTTG $\begin{array}{llllllllllllllllllll}L & Q & Q & L & G & A & T & I & D & W & I & T & \underset{w}{*} & Q & A & S & A & H & \underset{w}{H} & V\end{array}$ ATTGTCAGCGGATTATTCTTGCCGGGTTTTCGGCTGGCGGCCACGTGGTTGCGACTTATA \begin{tabular}{llllllll|lllll|lllllll}
$D$ & $C$ & $Q$ & $R$ & $I$ & $I$ & $L$ & $A$ & $G$ & $F$ & $\underline{\mathbf{S}}$ & $A$ & $G$ & $G$ & $H$ & $V$ & V & $A$ & $T$ & $Y$
\end{tabular} ATGGTGTTGCGACCCAACCAGAATTGCGCACACGGTATCATTTGGATCATTATCAAGGCC $\begin{array}{lllllllllllllllllllllll}N & G & V & A & T & Q & P & E & L & R & T & R & Y & H & L & D & H & Y & Q & G\end{array}$ AGCATGCTGCCATTATTTTAGGCTATCCAGTCATTGATTTGACAGCGGGGTTTCCCACGA $\begin{array}{llllllllllllllllllll}Q & H & A & A & I & I & L & G & Y & P & V & I & D & L & T & A & G & F & P & T\end{array}$ CTTCGGCGGCGCGTAATCAGATTACCACGGATGCCCGGTTGTGGGCAGCCCAGCGCCTAG $\begin{array}{llllllllllllllllllll}T & S & A & A & R & N & Q & I & T & T & D & A & R & L & W & A & A & Q & R & L\end{array}$ TCACACCAGCTAGTAAACCCGCTTTTGTCTGGCAAACGGCGACGGATGAGTCGGTCCCGC $\begin{array}{llllllllllllllllllll}V & T & P & A & S & K & P & A & F & V & W & Q & T & A & T & D & E & S & V & P\end{array}$ CAATCAATTCGTTAAAATATGTGCAGGCCATGCTACAACATCAGGTCGCAACTGCGTATC $\begin{array}{llllllllllllllllllll}P & I & N & S & L & K & Y & V & Q & A & M & L & Q & H & Q & V & A & T & A & Y\end{array}$ ATTTATTTGGTAGTGGGATTCATGGGTTAGCGTTAGCCAATCATGTGACGCAAAAACCTG $\begin{array}{llllllllllllllllllll}H & L & F & G & S & G & I & H & G & L & A & L & A & N & H & V & T & Q & K & P\end{array}$ GCAAGGACAAGTATTTGAATGACCAGGCTGCAATATGGCCACAATTAGCATTGCGGTGGT $\begin{array}{lllllllllllllllllllll}G & K & D & K & Y & L & N & D & Q & A & A & I & W & P & Q & L & A & L & R & W\end{array}$ TACAAGAACAGGGATTGTTAGCTGGTAATTATTGAAAATAAATCTGGGCGATCAGTCGTG $\begin{array}{llllllllllllllll}L & Q & E & Q & G & L & L & A & G & N & Y & *\end{array}$

CTTCACTGATCGCCCGTTTTTTGTCAACGATCCTGACACCAATTAATTTTCTGCGGTATA ATAATACGAATAAGCTTATTAAGTAAGAAGGAGCGATTGAGATGGCAACAAATCAACACT TGGTCATTATTTCCTTAGATGCGTTAGGATTTCGTGATTTACGCGAACATCAAGCAGAAT TACCCGTTCTGAGTGGATTGATGACCGGTGGTACTTGGGTCAAGTCGGTGACAGGCATTT

\section{Figure 3}

Nucleotide and deduced amino acid sequences of opdC gene from L. plantarum WCP931. Bold letters and underlines the start codon and serine residue. The stop codon is indicated by asterisk. The consensus sequences region is indicated by yellow box. 


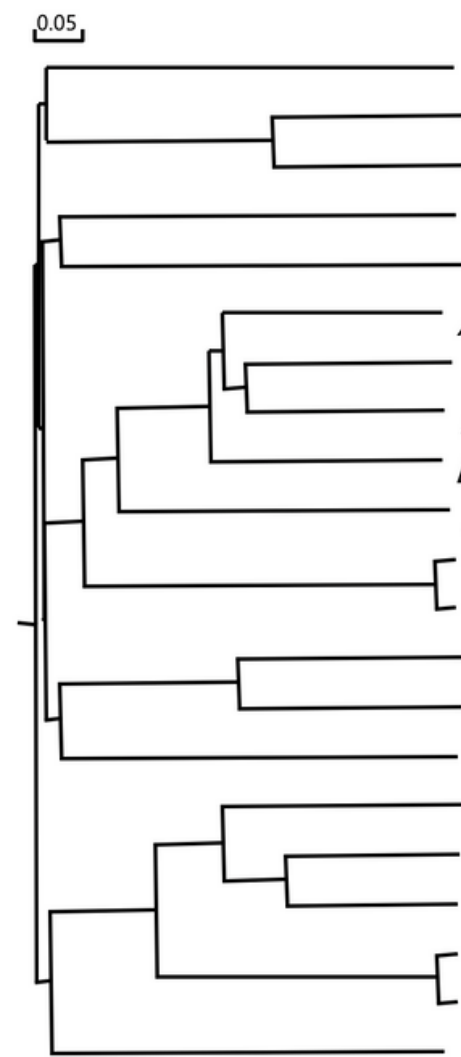

\section{$\angle b r-O p d B$}

Lpl-OpdC

Lsa-OpdD

Lme-OpdA

Lme-OpdE

A. thaliana (AAB84335)

A. azollae (AF035558)

H. sapiens (NP_001975)

E. coli $\mathrm{K} 12$ (AAC73458)

S. cerevisiae S288C (CAA84054)

L. lactics MG1363 (AAF02201)

L. lactics MG1363 (AF157601)

S. albus (AAA53485)

S. colicolor (NP_625018)

Uncultured bacterium (AF223645)

S. aureus (AAA26633)

S. epidermidis (AF090142)

L. casei CL96 (AY251019)

G. stearothermophilus P1 (AF237623)

G. thermocatenulatus DSM730 (CAA64621)

D. radiodurans $\mathrm{R} 1$ (AAF09912)
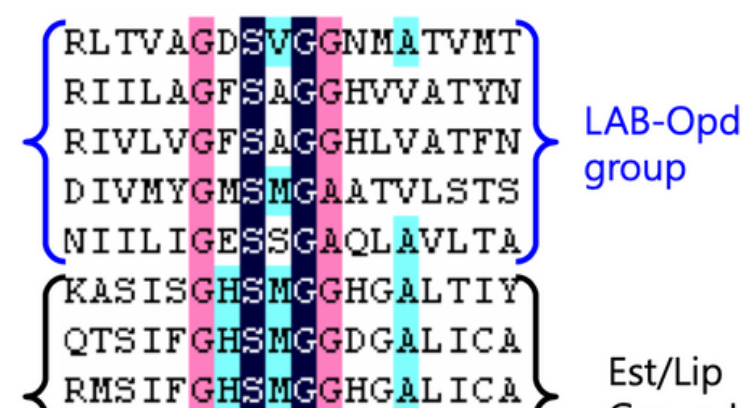

KKSISGHSMGGLGẢLVL ג $\}$ Group I

WV A I TGHSMGGYG ICGY)

$\{$ KNF I ẢGLSMGGYGAYRLẢ $\}$ Est/Lip

KNF I AGLSMGGYGAYRLA $\}$ Group II

RLGVIGHSMGGGGTLE Aू

$\{$ RLGVMGHSMGGGGTLE À $\}$

New Est/Lip

RVGASGHSQGGAGTIMAG group

KVHLVGHSMGGQTIRLME

$\{$ KIHLVGHSMGGQTIRLME

Est/Lip

KIHF IGHSMGGQTIRQME $\}$ Group IV

$\left\{\begin{array}{l}\text { RIH I I ÄHSQGGQT ÄRMLV } \\ \text { RVH I I ÄHSQGGQTARMLV }\end{array}\right\}$ Est/Lip

Group III

$s g$

\section{Figure 4}

Phylogenetic tree showing the evolutionary relatedness and levels of homology between the esterolytic and lipolytic enzyme amino acid sequences and the alignment of the conserved regions found in the primary esterolytic and lipolytic enzymes. 

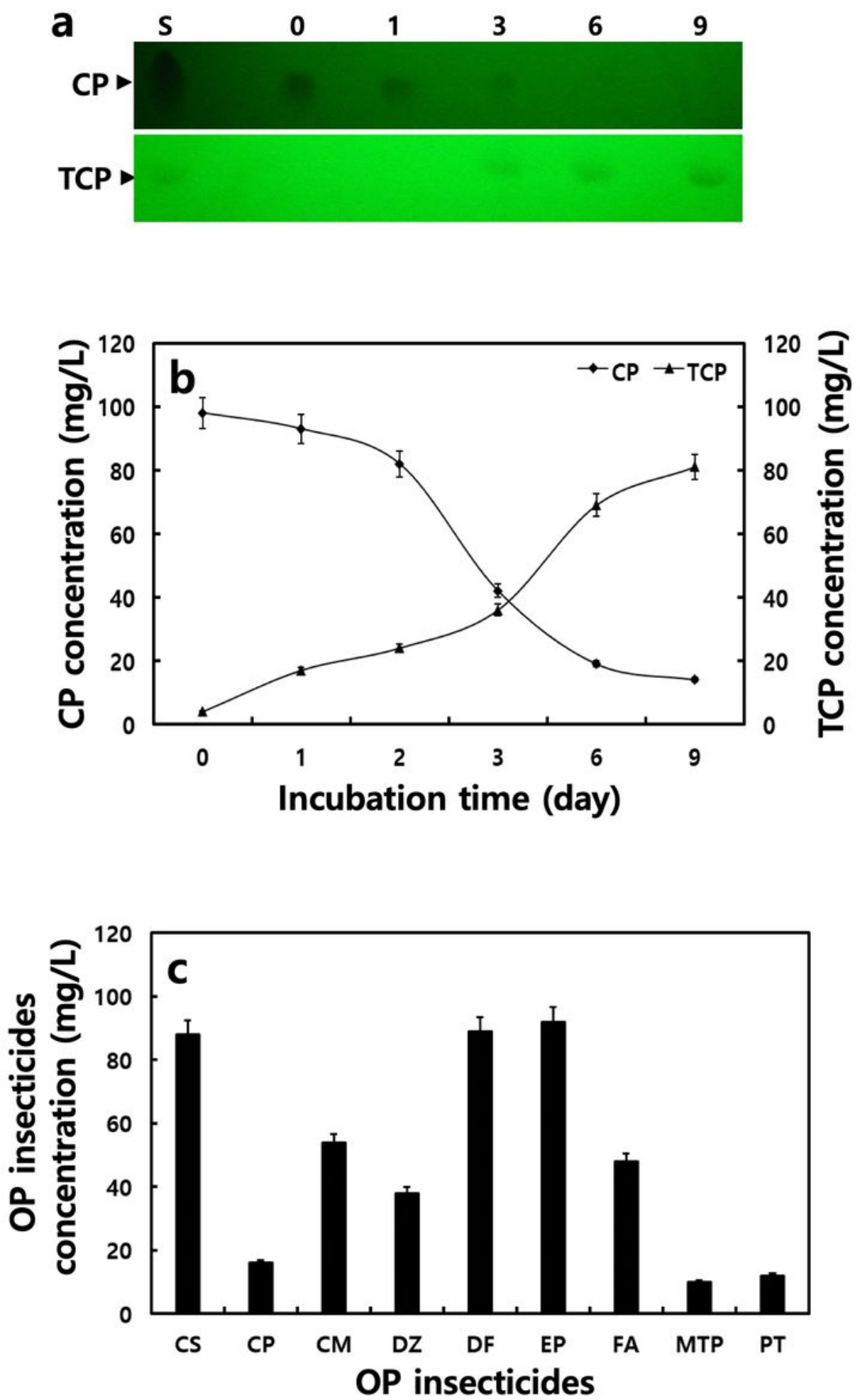

Figure 5

a TLC profile and $b$ changes of CP and TCP concentration of the recombinant E. coli with ophC gene growing in the M9 medium containing $100 \mathrm{mg} / \mathrm{L}$ of $\mathrm{CP}$ for 9 days. The standard errors were within $5 \%$ of the mean. 

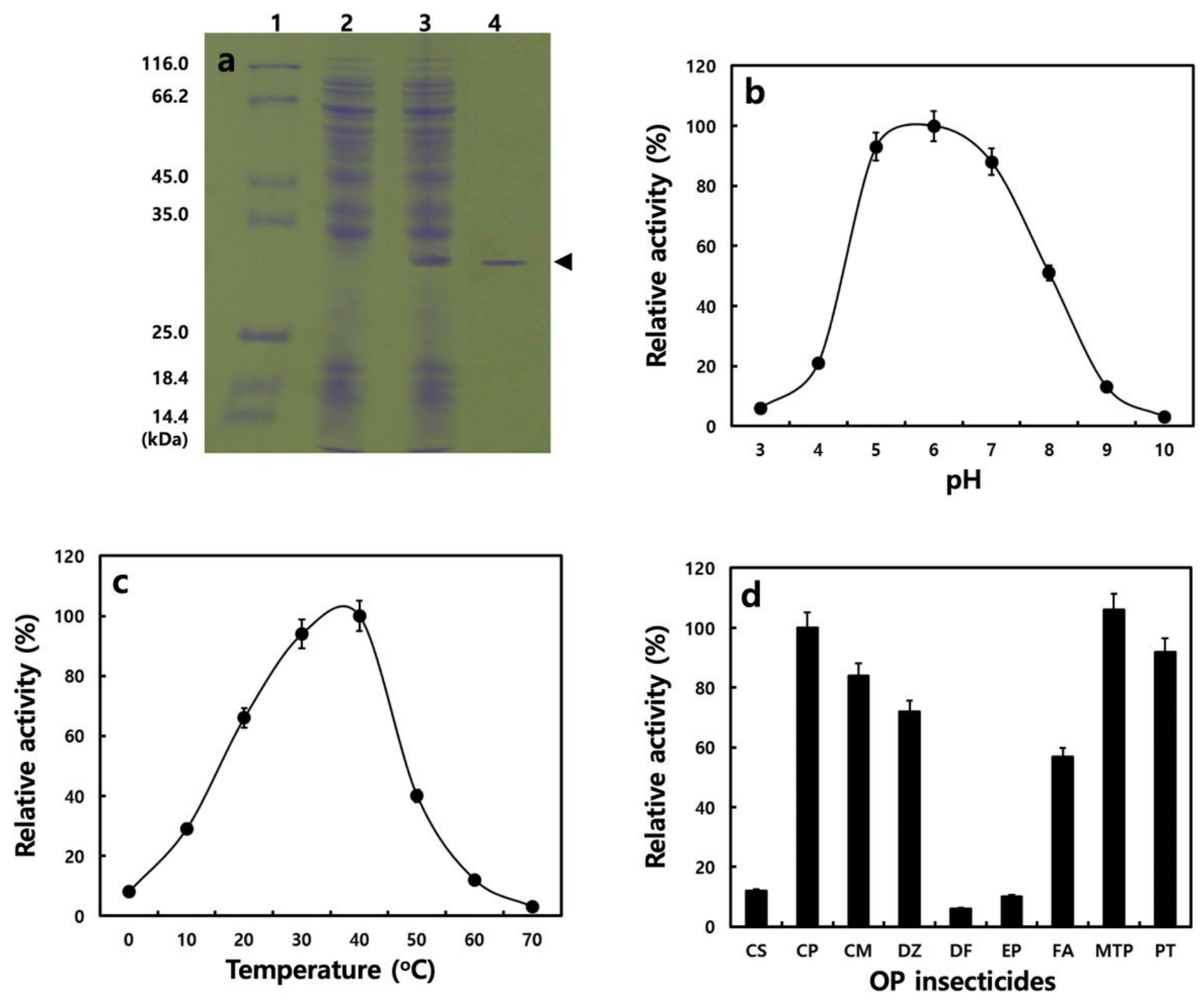

Figure 6

a Electrophoretic analysis of the purified OpdC. Separation was performed on a $12.5 \%(\mathrm{w} / \mathrm{v})$ SDS polyacrylamide gel and after was stained with $0.025 \%$ Coomassie blue R-250. Lane 1, standard marker; lane 2, crude extract from E. coli BL21 (DE3) containing pET-32(+)/OpdC; lane 3, crude extract from IPTGinduced E. coli BL21 (DE3) containing pET-32(+)/OpdC; lane 4, purified OpdC protein from Hi-Trap kit (Amersham). b pH effect on the relative activity of OpdC. The esterase activity of OpdC was assayed using $\rho N P B$ as substrate at different $\mathrm{pH}$ values at $40 \mathrm{oC}$ for $1 \mathrm{~h}$. $\mathrm{c}$ Effect of temperature on the relative activity of OpdC. The esterase activity of OpdC was assayed using $\rho N P B$ as substrate at different temperature values at $\mathrm{pH} 6.0$ for $1 \mathrm{~h}$. d Substrate relative activities of OpdC on the various organophosphorus (OP) insecticides, including cadusafos (CS), chlorpyrifos (CP), comnaphos (CM), diazinon (DZ), dyfonate (DF), ethoprophos (EP), fenamiphos (FA), methylparathion (MPT), and parathion (PT), as substrate at $40 \mathrm{oC}$ at $\mathrm{pH} 6.0$ for $12 \mathrm{~h}$. The standard errors were within $5 \%$ of the mean. 

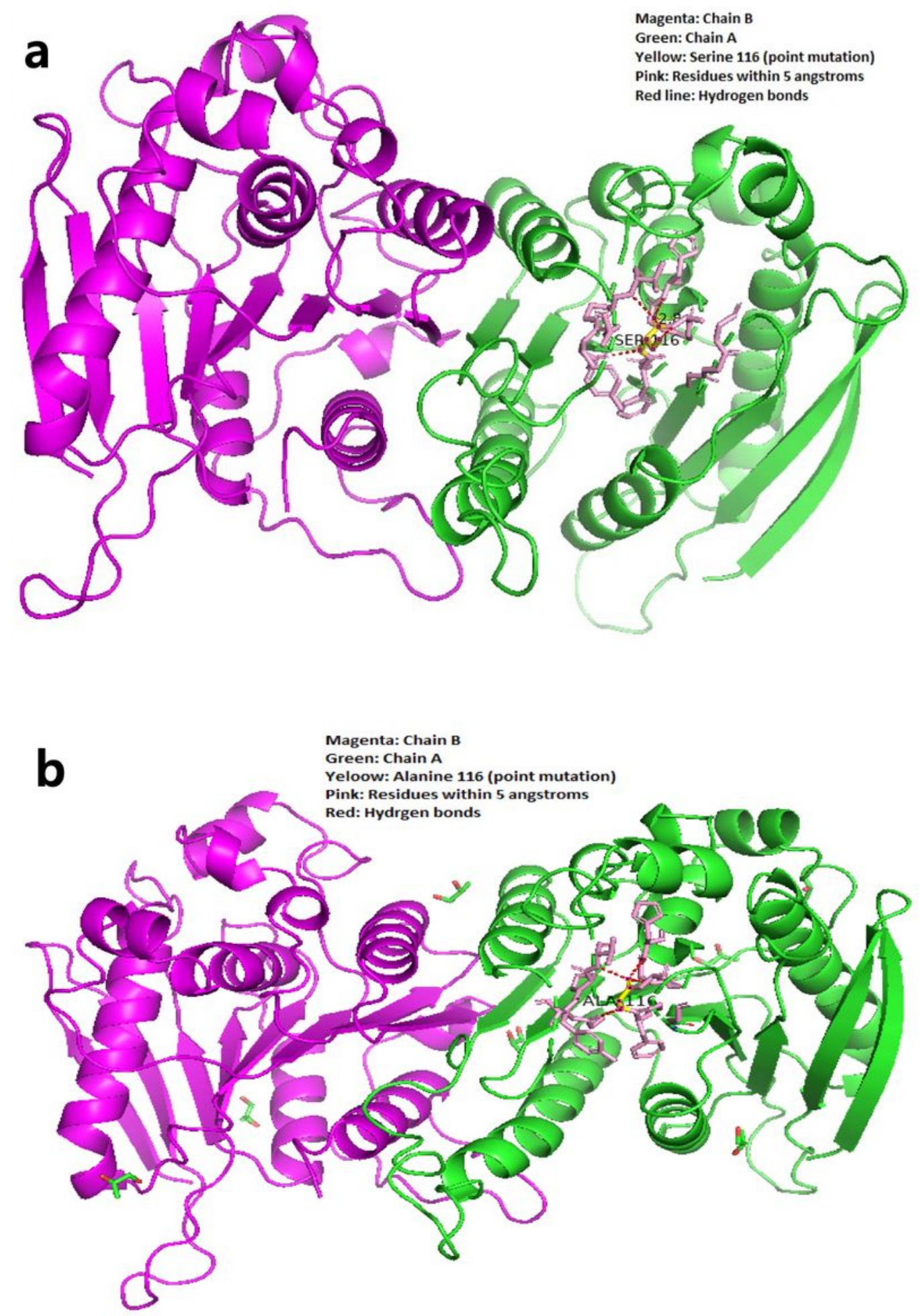

Figure 7

a Predictive active site of the OpdC protein and $\mathrm{b}$ predictive active site of the $\mathrm{OpC}$ mutant. The modeling was designed based on an esterase protein from protein data bank (accession number: $4 \mathrm{bzw}$ ). After that 4 bzw was used to get an alignment with OpdC with the help of 'Clustal Omega', then the clustal file was selected and used to find a secondary similarity analysis between the OpdC and 4bzw using 'ESPrit3'. 


\section{Supplementary Files}

This is a list of supplementary files associated with this preprint. Click to download.

- Supplementarymaterial20200411.docx 